\title{
PENGARUH CITRA PERUSAHAAN DAN REPUTASI TERHADAP KUALITAS PELAYANAN DAN DAMPAKNYA \\ PADA KEPUASAN PELANGGAN \\ (Pada Nasabah Tabungan Bank Artha Graha)
}

\author{
Kevin \\ Program Studi Magister Manajemen Universitas Tarumanagara \\ Kevinyehuda20@gmail.com \\ Mukti Rahardjo \\ Program Studi Magister Manajemen Universitas Tarumanagara
}

\begin{abstract}
This study aims to analyze the influence of corporate image and reputation on service quality and its impact on customer satisfaction in PT. Bank Artha Graha Tbk. This research used quantitative methods. The data is the primary data obtained through the distribution of questionnaires. The population in this study was customers of Bank Artha Graha, Tbk. The number of samples was determined by using Hair et.al. (1998) sampling method that is at least 5 times the number of parameters used in the study. The number of sample collected was 215 respondents. Using multiple linear regression analysis, it was found that corporate image and company reputation to have direct and significant positive effect on service quality and customer satisfaction on Bank Tabungan Graha Bank Tabungan Graha. Corporate image and company reputation has contributed $77.1 \%$ to the quality of service. In addition, the quality of service has direct and significant positive impact on service satisfaction on the Bank Tabungan Graha Bank Tabungan Graha. Contribution of company influence, company reputation and service quality equal to $71,5 \%$ to customer satisfaction. Corporate image has indirectly affected customer satisfaction through service quality at Bank Artha Graha Tbk that is 5,5\% similarly, Company Reputation has indirectly influence to customer satisfaction through service quality at Bank Artha Graha Tbk that is equal to 5,3\%. To improve customer satisfaction the company must maintain the corporate image abd reputation of the company through the quality of service.
\end{abstract}

Keywords: Company Image, Reputation, Service Quality and Customer Satisfaction

\section{PENDAHULUAN}

Setiap bidang usaha, terutama usaha yang menyediakan layanan khususnya jasa, tidak akan pernah terlepas dari reputasi dan kualitas pelayanan, diketahui dengan cara membandingkan persepsi nasabah atas layanan yang benar-benar diterima dengan layananan yang diharapkan. Dengan banyaknya perbankan yang ada, Bank Artha Graha menghadapi persaingan yang ketat sehingga Bank Artha Graha berupaya meningkatkan reputasi dan kualitas layanan dengan cara memenuhi apa yang dibutuhkan dan dianggap penting oleh nasabah. Setiap nasabah pasti berharap untuk mendapatkan pelayanan yang baik. Pemberi jasa juga memiliki standar kualitas dalam memberikan jasanya, maka setiap nasabah akan nyaman dengan produk yang ditawarkan. Lebih lanjut disampaikan informasi keluhan-keluhan nasabah pada bank Artha Graha antara lain; lamanya pelayanan yang diberikan, karyawan kurang sigap dalam melayani nasabah, karyawan kurang ramah dalam menangani nasabah. Berdasarkan uraian ini dapat diketaui bahwa citra perusahaan dan kualitas pelayanan berpengaruh terhadap kepuasan pelanggan/nasabah. Salah satu factor yang menentukan kepuasan pelanggan adalah persepsi pelanggan mengenai kualitas jasa yang berfokus pada kelima 
dimensi jasa. Beberapa studi peneliatian menunjukan bahwa kualitas pelayanan mempengaruhi kepuasan pelanggan yang akan berdampak pada minat beli ulang. Semakin tinggi tingkat kualitas, semakin tinggi pula tingkat kepuasan pelanggan yang dihasilkan (Kotler dan Keller, 2009).

Berdasarkan latar belakang penelitian di atas, penelitian ini bertujuan untuk menganalisis pengaruh citra perusahaan dan reputasi terhadap kualitas pelayanan dan dampaknya pada kepuasan pelanggan pada PT. Bank Artha Graha Tbk.

\section{TINJAUAN PUSTAKA}

Variabel-variabel dalam penelitian ini adalah (1) variable terikat (dependen), merupakan variabel yang dipengaruhi atau yang menjadi akibat, karena adanya variabel bebas (sugiono, 2010:59). Variabel terikat dalam penelitian ini adalah Kualitas pelayanan (Y) dan Kepuasan Pelanggan (Z). (2) Variabel bebas (independen), merupakan variabel yang memperngaruhi atau menjadi sebab perubahan atau timbulnya variabel dependen/terikat (Sugiono, 2010:59). Variabel bebas dalam penelitian ini adalah Citra Perusahaan (X1), dan reputasi (X2). Definisi variabel dalam penelitian ini adalah sebagai berikut:

\section{Citra Perusahaan}

Menurut Pradipta (2012) "Citra perusahaan (corporate image) merupakan representasi dari keseluruhan persepsi terhadap perusahaan dan dibentuk dari informasi dan pengalaman masa lalu terhadap perusahaan“. Kesan-kesan yang terkait perusahaan akan semakin meningkat dengan semakin banyaknya pengalaman nasabah dalam bekerjasama disuatu perusahaan atau dengan semakin seringnya mendengar perusahaan tersebut dalam strategi komunikasi. Sebuah perusahaan adalah seperangkat asosiasi, biasanya terangkai dalam bentuk yang bermanfaat.

\section{Reputasi Perusahaan}

Reputasi perusahaan model psikologi yang mempengaruhi persepsi kualitas produk atau jasa yang disediakan oleh perusahaan. Argenti dan BobDruckenmiller (2004) mendefinisikan "reputasi perusahaan sebagai gabungan dari berbagai macam image yang mewakili suatu perusahaan". Yang mana reputasi ini dibangun sejak lama yang berdasarkan identitas perusahaan, kinerja perusahaan serta bagaimana masyarakat mempersepsikan perilaku perusahaan tersebut.

\section{Kualitas Pelayanan}

Wyckof sebagaimana dikutip dari Tjiptono (2008:260) menyatakan "kualitas pelayanan sebagai tingkat keunggulan yang diharapkan dan pengendalian atas keunggulan tersebut untuk memenuhi keinginan pelanggan". Dengan kata lain terdapat dua faktor utama yang mempengaruhi kualitas pelayanan, yakni pelayanan yang diharapkan dan pelayanan yang dipersepsikan (Parasuraman et.al. sebagaimana dikutip dari Tjiptono, 2008:260). Pada prinsipnya definisi kualitas pelayanan berfokus pada upaya pemenuhan dan keinginan pelanggan, serta ketepatan penyampaiannya untuk mengimbangi harapan pelanggan (Tjiptono, 2008:260).

\section{Kepuasan Konsumen}

Kotler dalam buku Sangadji dan Sopiah (2013:181) mengatakan "kepuasan adalah sejauh mana suatu tingkatan produk dipersepsikan sesuai harapan pembeli”. Jadi, kepuasan konsumen diartikan sebagai suatu keadaan dimana harapan konsumen terhadap suatu jasa atau produk sesuai dengan kenyataan yang diterima oleh konsumen. Jika jasa atau produk tersebut jauh di bawah harapan, konsumen akan kecewa. Sebaliknya jika jasa atau produk tersebut memenuhi harapan, maka konsumen akan puas. 
Dari tinjauan teori diatas, terdeteksi secara koseptual tentang keterkaitan citra perusahaan (X1) dan reputasi (X2) terhadap kualitas pelayanan (Y) serta dampaknya pada kepuasan pelanggan $(\mathrm{Z})$, seperti terlihat pada gambar 1. Berikut ini:

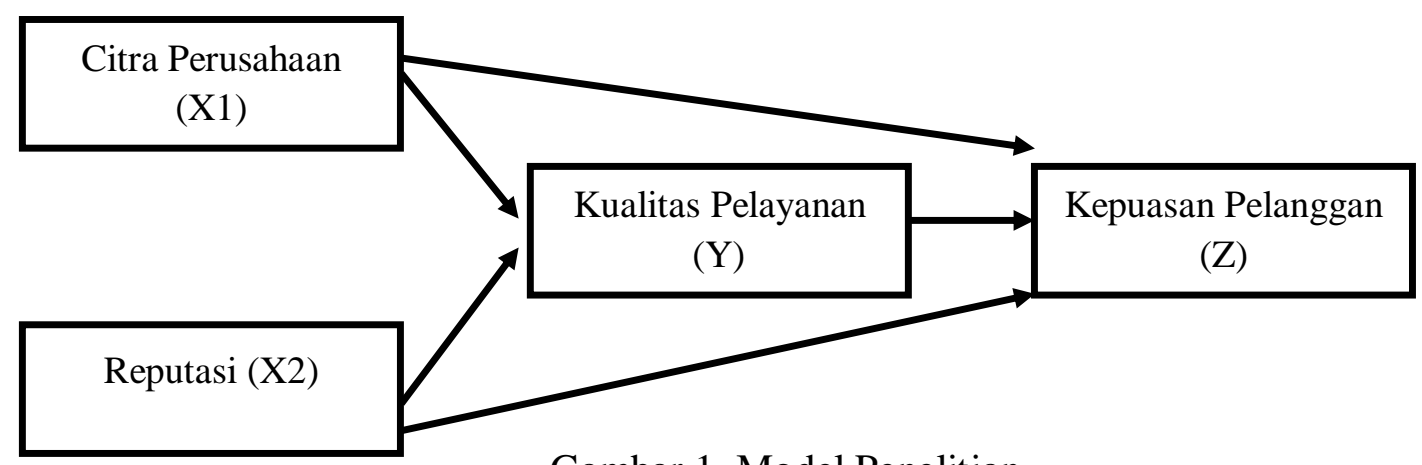

Gambar 1. Model Penelitian

\section{Hipotesis}

Adapun hipotesis yang diajukan dalam penelitian antara lain:

H1 : Terdapat pengaruh citra perusahaan terhadap kualitas pelayanan

$\mathrm{H} 2$ : Terdapat pengaruh reputasi terhadap kualitas pelayanan

H3 : Terdapat pengaruh citra perusahaan terhadap kepuasan pelanggan

H4 : Terdapat pengaruh reputasi terhadap kepuasan pelanggan

H5 : Terdapat pengaruh kualitas pelayanan terhadap kepuasan pelanggan

H6 : Terdapat pengaruh citra perusahaan terhadap kepuasan pelanggan melalui kualitas pelayanan

H7 : Terdapat pengaruh reputasi terhadap kepuasan pelanggan melalui kualitas pelayanan

\section{METODOLOGI PENELITIAN}

Penelitian ini menggunakan pendekatan kuantitatif, Menurut Sugiyono (2012:11) menyatakan "metode kuantitatif dapat diartikan sebagai metode penelitian yang berlandaskan pada filsafat positivism, digunakan untuk meneliti pada populasi atau sampel tertentu, pengumpulan data menggunakan instrument penelitian, analisis data bersifat kuantitatif/statistik, dengan tujuan untuk menguji hipotesis yang telah ditetapkan". Populasi dalam penelitian ini adalah nasabah Bank Artha Graha, Tbk. untuk menentukan besarnya ukuran sampel digunakan rumus Hair et.al. (1998) sehingga ditentukan sebanyak 215 responden. Jenis data yang digunakan dalam penelitian ini terdiri dari data primer dan data sekunder. Data primer yang dikumpulkan dengan teknik penyebaran kuesioner, yaitu dengan memberikan pernyataan tertulis kepada responden, dalam hal ini adalah nasabah Bank Artha Graha, Tbk. Data sekunder yang digunakan peneliti adalah data dari bahan-bahan kepustakaan, buku-buku dan sumber yang berkaitan.

\section{HASIL DAN PEMBAHASAN}

Analisis jalur digunakan untuk mengetahui pengaruh langsung dan tidak langsung antar variabel - variabel tersebut. Berikut hasil perhitungan analisis jalur, seperti pada tabel berikut ini:

Tabel 1. Rangkuman Hasil Koefisien Analisis Jalur

\begin{tabular}{ccccc}
\hline Hubungan Variabel & Koefisien & Nilai t & Nilai & Keterangan \\
\hline
\end{tabular}




\begin{tabular}{lrrrl}
\hline & Jalur $\mathbf{( B e t a )}$ & \multicolumn{1}{c}{ Sig } \\
\hline Citra Perusahaan $\rightarrow$ Kualitas Pelayanan & 0,309 & 10,291 & 0,000 & Signifikan \\
\hline Reputasi $\rightarrow$ Kualitas Pelayanan & 0,287 & 7,364 & 0,000 & Signifikan \\
\hline Citra Perusahaan $\rightarrow$ Kepuasan Pelanggan & 0,262 & 5,725 & 0,000 & Signifikan \\
\hline Reputasi $\rightarrow$ Kepuasan Pelanggan & 0,251 & 4,612 & 0,000 & Signifikan \\
\hline Kualitas Pelayanan $\rightarrow$ Kepuasan Pelanggan & 0,210 & 2,452 & 0,015 & Signifikan \\
\hline
\end{tabular}

Perhitungan Error Tem :

$\begin{aligned} \text { Error term }\left(\mathrm{e}_{1}\right) & =\sqrt{1-\mathrm{R}^{2}} & \text { Error term }\left(\mathrm{e}_{2}\right) & =\sqrt{1-\mathrm{R}^{2}} \\ & =\sqrt{1-0,774} & & =\sqrt{1-0,719} \\ & =\sqrt{0,226} & & =\sqrt{0,281} \\ & =0,475 & & =0,530\end{aligned}$

Pemeriksaan validitas model :

Hasil perhitungan koefisien determinasi total dapat dilihat sebagai berikut :

$$
\begin{aligned}
\mathrm{R}^{2} \mathrm{~m} & =1-\left(\mathrm{e}_{1}\right)^{2}\left(\mathrm{e}_{2}\right)^{2} \\
& =1-(0,475)^{2}(0,530)^{2} \\
& =0,937
\end{aligned}
$$

Hasil koefisien determinasi total menunjukkan bahwa keragaman data dapat dijelaskan oleh model adalah sebesar 93,7\%. Dapat dijelasakan bahwa informasi yang terkandung dalam data sebesar 93,7\% dapat dijelaskan oleh model, sedangkan sisanya yaitu 6,3\% dijelaskan oleh variabel lain yang tidak terdapat pada model. Mengacu pada tabel 4.10 dan hasil perhitungan error tem, maka dapat digambarkan model Path Analysis seperti gambar berikut ini :

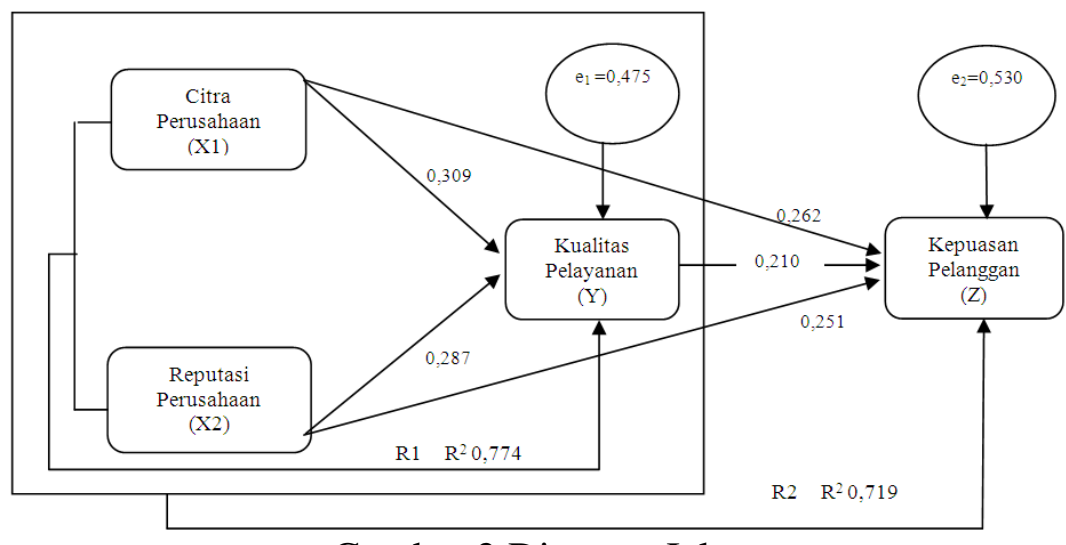

Gambar 2 Diagram Jalur

\section{Pengaruh Langsung (Direct Effect atau DE)}

a. Pengaruh langsung variabel citra perusahaan terhadap kualitas pelayanan dapat dilihat dari standard coefficient beta adalah sebesar 0,309 dengan nilai signifikan sebesar 0,000 .

b. Pengaruh langsung variabel reputasi perusahaan terhadap kualitas pelayanan dapat dilihat dari standard coefficient beta adalah sebesar 0,287 dengan nilai signifikan sebesar 0,000 .

c. Pengaruh langsung variabel citra perusahaan terhadap kepuasan pelanggan dapat dilihat dari standard coefficient beta adalah sebesar 0,262 dengan nilai signifikan sebesar 0,000 .

d. Pengaruh langsung variabel reputasi perusahaan terhadap kepuasan pelanggan dapat dilihat dari standard coefficient beta adalah sebesar 0,251 dengan nilai signifikan sebesar 0,000 .

e. Pengaruh langsung variabel kualitas pelayanan terhadap kepuasan pelanggan dapat dilihat dari standard coefficient beta adalah sebesar 0,210 dengan nilai signifikan sebesar 0,015 . 


\section{Pengaruh Tidak Langsung (Indirect Effect atau IE)}

a. Pengaruh variabel citra perusahaan terhadap kepuasan pelanggan melalui kualitas pelayanan didapat dengan cara:

$$
\begin{aligned}
& \rho 1 \times \rho 2=0,262 \times 0,210 \\
& =0,055 .
\end{aligned}
$$

Nilai 0,055 menyatakan bahwa pengaruh tidak langsung citra perusahaan terhadap kepuasan pelanggan melalui kualitas pelayanan adalah sebesar 5,5\%..

b. Pengaruh variabel reputasi perusahaan terhadap kepuasan pelanggan melalui kualitas pelayanan didapat dengan cara:

$$
\begin{aligned}
& \rho 1 \times \rho 2=0,251 \times 0,210 \\
& =0,053 .
\end{aligned}
$$

Nilai 0,053 menyatakan bahwa pengaruh tidak langsung reputasi perusahaan terhadap kepuasan pelanggan melalui kualitas pelayanan adalah sebesar 5, 3\%.

\section{Pengaruh Total (Total Effect)}

a. Pengaruh variabel citra perusahaan dan kualitas pelayanan terhadap kepuasan pelanggan adalah sebesar $(0,309+0,055)=0,364$.

b. Pengaruh variabel reputasi perusahaan dan kualitas pelayanan terhadap kepuasan pelanggan adalah sebesar $(0,287+0,053)=0,340$.

\section{Pembahasan Hasil Penelitian}

\section{Citra Perusahaan berpengaruh terhadap Kualitas Pelayanan}

Hipotesis pertama menunjukkan bahwa citra perusahaan terbukti memiliki pengaruh langsung dan positif signifikan terhadap kualitas pelayanan pada Nasabah Tabungan Bank Artha Graha Tbk. Berpengaruh positif signifikan memiliki arti bahwa semakin tinggi citra perusahaan maka semakin tinggi kualitas pelayanan yang diberikan kepada Nasabah Tabungan Bank Artha Graha Tbk. Hipotesis yang dirumuskan pada penelitian ini menunjukkan hasil yang relatif sama dan mendukung beberapa penelitian terdahulu seperti Salam dan Shawky (2013) dan Haerudin (2010) memperlihatkan bahwa citra perusahan memiliki pengaruh yang signifikan terhadap kepuasan nasabah.

\section{Reputasi Perusahaan berpengaruh terhadap Kualitas Pelayanan}

Hipotesis kedua menunjukkan bahwa reputasi perusahaan terbukti memiliki pengaruh langsung dan positif signifikan terhadap kualitas pelayanan pada Nasabah Tabungan Bank Artha Graha Tbk. Berpengaruh positif signifikan memiliki arti bahwa semakin tinggi reputasi perusahaan maka semakin tinggi kualitas pelayanan yang diberikan kepada Nasabah Tabungan Bank Artha Graha Tbk. Hasil Hipotesis mendukung penelitian yang dilakukan oleh Tabrani dan Muchfidh (2016) dan Salam dan Shawky (2013) bahwa reputasi perusahaan berpengaruh terhadap kualitas pelayanan.

\section{Citra Perusahaan berpengaruh terhadap Kepuasan Pelanggan}

Hipotesis ketiga menunjukkan bahwa citra perusahaan terbukti memiliki pengaruh langsung dan positif signifikan terhadap kepuasan pelanggan pada Nasabah Tabungan Bank Artha Graha Tbk. Berpengaruh positif signifikan memiliki arti bahwa semakin citra perusahaan maka semakin tinggi kepuasan pelanggan yang diberikan kepada Nasabah Tabungan Bank Artha Graha Tbk. Citra suatu perusahaan merupakan faktor yang sering mempengaruhi keputusan pembelian. Citra tidak dapat diciptakan seperti membuat barang dari pabrik, akan tetapi citra merupakan kesan yang diperoleh sesuai dengan pengetahuan dan pemahaman seseorang tentang sesuatu.

\section{Reputasi Perusahaan berpengaruh terhadap-Kepuasan Pelanggan}


Hipotesis empat menunjukkan bahwa reputasi perusahaan terbukti memiliki pengaruh langsung dan positif signifikan terhadap kepuasan pelanggan pada Nasabah Tabungan Bank Artha Graha Tbk. Berpengaruh positif signifikan memiliki arti bahwa semakin reputasi perusahaan maka semakin tinggi kepuasan pelanggan yang diberikan kepada Nasabah Tabungan Bank Artha Graha Tbk.

\section{Kualitas Pelayanan berpengaruh terhadap Kepuasan Pelanggan}

Hipotesis kelima menunjukkan bahwa kualitas pelayanan terbukti memiliki pengaruh langsung dan positif signifikan terhadap kepuasan pelanggan pada Nasabah Tabungan Bank Artha Graha Tbk. Berpengaruh positif signifikan memiliki arti bahwa semakin kualitas pelayanan maka dapat memberikan pengaruh pada meingkatnya kepuasan pelanggan yang merupakan Nasabah Tabungan Bank Artha Graha Tbk. Hasil penelitian ini mendukung penelitian yang dilakukan oleh Aryani dan Rosinta (2010) bahwa kelima dimensi pembentuk kualitas layanan terbukti berpengaruh secara signifikan terhadap kualitas layanan.

\section{Citra Perusahaan berpengaruh terhadap Kepuasan Pelanggan melalui Kualitas Pelayanan}

Citra perusahaan tidak berpengaruh langsung terhadap kepuasan pelanggan melalui kualitas pelayanan di Bank Artha Graha Tbk. Hasil penelitian menunjukkan bahwa pengaruh tidak langsung variabel citra perusahaan terhadap kepuasan pelanggan melalui kualitas pelayanan berada pada ketegori sangat lemah yaitu sebesar 5,5\%. Hasil Hipotesis ini mendukung penelitian yang dilakukan oleh Salam dan Shawky (2013) bahwa citra perusahaan berpengaruh terhadap kualitas pelayanan dan berdampak pada kepuasan pelanggan.

\section{Reputasi Perusahaan berpengaruh terhadap Kepuasan Pelanggan melalui Kualitas Pelayanan}

Reputasi perusahaan terbukti tidak berpengaruh langsung terhadap kepuasan pelanggan melalui kualitas pelayanan di Bank Artha Graha Tbk. Hal ini menjelaskan bahwa reputasi perusahaan berpengaruh terhadap kualitas pelayanan yang pada akhirnya akan mempengaruhi kepuasan pelanggan yaitu sebesar 5, 3\%. Hasil Hipotesis ini mendukung penelitian yang dilakukan oleh Salam dan Shawky (2013) bahwa reputasi perusahaan berpengaruh terhadap kualitas pelayanan dan berdampak pada kepuasan pelanggan.

\section{KESIMPULAN DAN SARAN}

\section{Kesimpulan}

Kesimpulan hasil penelitian ini yaitu:

1. Citra perusahaan terbukti memiliki pengaruh langsung dan positif signifikan terhadap kualitas pelayanan pada Nasabah Tabungan Bank Artha Graha Tbk.

2. Citra perusahaan terbukti memiliki pengaruh langsung dan positif signifikan terhadap kepuasan pelanggan pada Nasabah Tabungan Bank Artha Graha Tbk.

3. Reputasi perusahaan terbukti memiliki pengaruh langsung dan positif signifikan terhadap kepuasan pelayanan pada Nasabah Tabungan Bank Arta Graha Tbk.

4. Kualitas pelayanan terbukti memiliki pengaruh langsung dan positif signifikan terhadap kepuasan pelayanan pada Nasabah Tabungan Bank Arta Graha Tbk.

\section{Saran}

1. Untuk Pimpinan disarankan dapat mempertahankan citra perusahaan dengan terus meningkatkan tanggung jawab sosial perusahaan melalui kepedulian terhadap lingkungan 


\section{DAFTAR PUSTAKA}

Argenti, Paul dan Bob Druckenmiller. (2004). Reputation and the Corporate Brand. Corporate Reputation Review, Vol 6, No 4, pp 368-374.

Aryani, D dan Rosinta, F. (2010). Pengaruh kualitas Layanan Terhadap Kepuasan Pelanggan Dalam Membentuk Loyalitas Pelanggan. Jurnal Ilmu Administrasi dan Organisasi, Vol.17, No.2.

Hapsari, Ajeng Peni. (2008). Analsiis Perbandingan Penggunaan Celebrity Endorser dan Typical-Person Endorser dan Hubungannya Dengan Brand Image Produk. Jurnal Bisnis dan Manajemen, Vol.1X, No.1.

Kotler dan Keller. (2009). Manajemen Pemasaran. Jilid I. Edisi ke 13. Jakarta: Erlangga.

Sugiono. 2010. Metode Penelitian Bisnis. Bandung: Alfabeta

Salam, E. M; Shawky, A; and Nahas, T. (2013), The impact of corporate image and reputation on service quality, customer satisfaction and customer loyalty: testing the mediating role. Case analysis in an international service company. The Business and Management Review, Vol 3, Number 2, pp. 177-196.

Sangadji, E.M., dan Sopiah. (2013). Prilaku Konsumen: Pendekatan Praktis Disertai: Himpunan Jurnal Penelitian. Yogyakarta: Penerbit Andi.

Sugiyono. (2012). Memahami Penelitian Kualitatif. Bandung: Alfabeta.

Tabrani, Mirza dan Muchfidh. (2016).Pengaruh reputasi perusahaan terhadap komitmen, kepercayaan, loyalitas dan dampaknya pada perilaku pelanggan (pada konsumen maskapai garuda Indonesia). Jurnal Mahasiswa, Vol. 1, No. 3, 1-8.

Tjiptono, Fandy. (2008). Strategi Bisnis Pemasaran. Yogyakarta: Andi. 


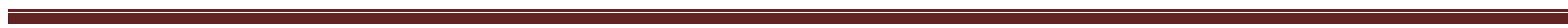
$\cdot$ 